\title{
Narrativas/Máquinas performáticas: \\ um diálogo \\ entre literatura \\ e performance
}

Writing/Performatic machines:

a dialogue between literature and performance

Daniel Almeida Machado

UFMS

Angela Maria Guida

UFMS 
Por seu caráter compósito, a literatura há muito revela-se enquanto terreno fértil para experimentação e diálogo com outras manifestações artísticas, como bem nos revela Roland Barthes em sua Aula (1977) e $S / Z$ (1970). Ademais, tendo em vista o incessante retorno do corpo como cerne de temas/discussões da estética contemporânea, torna-se possível pensar, sobremaneira, num diálogo entre a arte literária e a arte performática. Neste sentido, o presente trabalho pretende dialogar poemas da escritora gaúcha Angélica Freitas, em Um útero é do tamanho de um punho (2017), e performances da artista visual paraense Berna Reale, compreendendo a constituição do texto literário como uma "narrativa performática" (RAVETTI, 2002) e que o diálogo entre literatura e performance pode criar uma "máquina performática" (AGUILAR; CÁMARA, 2017).

Palavras-chave: Narrativas performáticas; Máquinas performáticas; Literatura e performance; Angélica Freitas; Berna Reale

\section{Abstract}

For its composite character, literature has long been revealed as a fertile ground for experimentation and dialogue with other artistic manifestations, as Roland Barthes reveals in his Lesson (1977) and $S / Z$ (1970). In addition, in view of the incessant return of the body as the core of themes/discussions of contemporary aesthetics, it becomes possible to think, in a great way, in a dialogue between literary art and performance art. In this sense, the present work intends to dialogue poems by the gaucho writer Angélica Freitas, in $A$ uterus is the size of a fist (2017), and performances by the visual artist from Pará, Berna Reale, understanding the constitution of the literary text as a "performative writing" (RAVETTI, 2002) and that the dialogue between literature and performance can create a "performatic machine" (AGUILAR;CÁMARA, 2017).

Keywords: Performative writing; Performatic machines; Literature and Performance; Angélica Freitas; Berna Reale 
A partir do exercício barthesiano com a novela Sarrasine, de Honoré de Balzac, e que o teórico expõe em $S / Z$, neste trabalho queremos estrelar o texto, isto é, partir de uma inflexão e criação de um modo de leitura que possa considerar o texto como um "céu estrelado", uma metáfora que apela à visão disforme e torrencial do texto literário e, por extensão, de tudo o que possa ser denominado sob a alcunha de "arte"1. Estrelar um texto não é fechá-lo enquanto escritura, "compactá-lo" como diria Barthes, mas considerá-lo em toda sua potencialidade de leituras, tal qual uma "galáxia de significantes" em que não haja uma "ordem de entrada" principal ou secundária².

Esta chave de liberdade não resulta de um abandono do que é literário ou artístico, pelo contrário, trata-se em deixar de lado o hábito sacralizado, tão corrente nos dias atuais, da incapacidade de comunicação. Se nunca conversamos, como poderemos nos encontrar? Se não estabelecermos um diálogo entre as artes, como supor um maior entendimento do discurso poético? Nesse sentido, a lição de Barthes é clara: não se trata de passar de "uma linguagem a um referente, mas de um código a outro código"’3, e com isso deixar de considerar a literatura, a pintura, a música, a escultura, a performance etc., como sistemas independentes e dispostos em uma ordem hierárquica.

Não sendo possível crer que diferentes formas de criação sejam distanciadas, ou separadas por graus de importância, Barthes chega a um questionamentoprovocação: "por que não anular a diferença?"4. Todavia, a prática barthesiana também não diz respeito sobre abandonar a especificidade de cada objeto artístico. Literatura é literatura, pintura é pintura, música é música, escultura é escultura, cinema é cinema, performance é performance, e assim por diante com qualquer manifestação artística, considerando inclusive sua impossibilidade de definição precisa. O que se pretende abandonar, na verdade, é a separação autoritária dos códigos e a supremacia de um em detrimento de outro, de modo que o/a leitor/a possa adentrar e passear pelos bosques de um quadro, em seguida de uma escultura, mais adiante de um texto literário, no

1 Conforme Barthes: “O texto, em sua totalidade, é comparável a um céu, plano e profundo ao mesmo tempo liso, sem bordos e sem referências; tal como o áugure, recortando com a ponta do bastão um ângulo fictício no céu para aí interrogar, segundo certos princípios, o vôo dos pássaros, o comentador traça ao longo do texto zonas de leitura para nelas observar a migração dos sentidos, o afloramento dos códigos, a passagem das citações”. BARTHES, Roland. S/Z, 1992, p. 47.

2 Ibidem, p. 49

3 Ibidem, p. 85.

4 Ibidem, p. 87. 
meio do caminho deparar-se com um filme, e tudo o que mais lhe aprouver enquanto perspectiva de uma correspondência entre as artes. Do que serve para a arte tornar-se apenas "O retrovisor da outra" ?

Desse modo, é o caso de pensar a literatura de Marguerite Duras, que se utiliza da técnica cinematográfica em $O$ amante e em outros de seus livros; da "Alquimia do verbo", de Rimbaud, que inventa a cor das vogais; do entrelaçamento de Em busca do tempo perdido, de Proust, com a pintura; ou de As Ondas, de Virginia Woolf, em constante diálogo com a música. Não fogem à regra os exemplos da literatura brasileira: Dom Casmurro, de Machado de Assis, é estruturado em forma de uma ópera; Stella Manhattan, de Silviano Santiago, possui uma troca explícita com a artista brasileira Lygia Clark e o escultor alemão Hans Bellmer; Água viva, de Clarice Lispector, descreve imagens que foram pintadas pela autora; ainda, faz-se necessário lembrar da "Semana de Arte Moderna”, de 1922, ocasião em que a literatura foi pensada nos moldes de Vanguardas Europeias como o Surrealismo, Futurismo, Expressionismo, Dadaísmo, entre outras, numa atitude de alegria antropofágica entre literatura e as mais variadas expressões artísticas. Poderíamos continuar apresentando exemplos de correspondência entre as artes, e seriam inúmeros, mas esses já permitem demonstrar a literatura como um espaço que pode englobar outras manifestações e campos do conhecimento.

Aliás, o processo globalizante do texto literário também foi analisado por Barthes naquela que pode ser considerada uma de suas maiores lições, quer seja a de que "a literatura assume muitos saberes", e, todavia, "não fetichiza nenhum deles", quer seja a de que não há saber maior ou saber menor, o mais ou menos adequado ${ }^{8}$. Tais assertivas, ditas em sua aula inaugural no Collége de France, foram sintetizadas numa bastante conhecida e peculiar abstração, com a qual Barthes demonstra toda a força do discurso poético em ultrapassar o código verbal:

\footnotetext{
Se, por não sei que excesso de socialismo ou de barbárie, todas as nossas disciplinas devessem ser expulsas do ensino, exceto uma, é a disciplina literária que devia ser salva, pois todas as ciências estão presentes no monumento literário. É nesse sentido que se pode dizer que a literatura [...] faz girar os saberes, não fixa, não fetichiza nenhum deles; ela lhes dá um lugar indireto, e esse indireto é precioso?.
}

\footnotetext{
5 Ibidem, p. 86.

6 Idem. Aula, 2007, p. 17.

7 Ibidem, p. 18.

8 "Tudo é matéria de poesia", já nos alertava Manoel de Barros.

9 Ibidem, p. 17-18.
} 
Da situação imaginada pelo pensador francês depreende-se um duplomovimento: o discurso poético pode englobar os saberes e esses saberes só podem formar-se no cerne de um diálogo. "Literatura, escritura ou texto"10 e "o tecido de significantes que constitui a obra" ${ }^{11}$ fazem com que a trapaça do texto incite o que o teórico pensa como uma permanente revolução da própria linguagem, no horizonte do improvável e do efêmero. Não obstante, ainda que Barthes faça menção explícita ao texto literário, e sabemos que todo texto possui um discurso, anterior ao próprio texto, podemos pensar que é o próprio discurso poético (e com isso toda manifestação artística) que faz girar os saberes. A própria noção de texto e o leitmotiv da semiologia barthesiana sempre foi a do alargamento e não da supressão, sustentando-se na afirmativa de que "tudo é um texto". Há, nas lições barthesianas, importantes defesas para considerarmos que o intercâmbio entre os sistemas semióticos das artes é uma das maneiras mais profícuas para que possamos aprofundar nossas leituras de um texto literário/artístico/poético.

No entanto, ainda que a correspondência interartística encontre um disposto interlocutor com as proposições teóricas de Barthes, oriundas a partir da segunda metade do século XX, podemos recuar um pouco mais. Um desdobramento histórico permite compreender uma inevitável recorrência ao diálogo, ou possíveis aproximações, entre aquilo que pensamos como arte, estejamos dispostos ou não a considerar tais interações. Talvez o exemplo mais antigo, e também dos mais significativos, seja o uso da expressão "Ut pictura poesis" de 20 a.C.. Ao referir-se ao texto literário e ao texto pictórico como criações que deveriam seguir certas prescrições, e fazendo uma espécie de comparação entre os dois, Horácio acidentalmente dá início a um frutífero debate com o qual se nutre a Literatura Comparada e os Estudos Interartes/Intermídias séculos mais tarde.

Comparando a pintura com a poesia, o poeta propunha que a primeira seguisse um modelo figurativo, não abstrato, e com isso emanasse ao real. Por conseguinte, a segunda também deveria manter-se restrita a determinados parâmetros, de harmonização e proporção, a exemplo da versificação bem marcada e o uso do coro e da música. Tais ideias eram concernentes com a Era Helenística, que legou ao Ocidente obras bastante precisas como a Vênus de Milo, Apolo Belvedere e a Vitória de Samotrácia. Milimetricamente pensadas, com um forte rigor quase científico, essas esculturas assemelham-se a uma imitação realista das formas humanas e tornam-se exemplos para um conceito de arte em que o belo ou o modelo a ser seguido, tal como pensava Horácio, deveria ser

\footnotetext{
10 Ibidem, p. 16.

11 Ibidem, p. 16.

12 "Como a pintura, é a poesia".
} 
o da proporção. Conforme assinala Solange Ribeiro de Oliveira (1993), a expressão horaciana questiona os atributos de uma poesia e pintura que fossem livres de um rigor formal: "que pensariam, pergunta Horácio, de um pintor que unisse uma cabeça humana ao pescoço de um cavalo, ou espalhasse plumas multicores sobre membros em esparsos, ou arrematasse o tronco de uma linda mulher com a cauda de um peixe repelente?" 13 . Ainda assim, as gerações posteriores subverteram a máxima horaciana, e, progressivamente, fizeram com que suas palavras pavimentassem os caminhos para uma abordagem crítica que dialogasse a literatura com a pintura, com a música, com o cinema e com os mais diversos tipos de manifestações artísticas. No contexto das aproximações possíveis, queremos pensar nas afinidades eletivas entre literatura e performance.

\section{Narrativas/máquinas performáticas}

$\mathrm{Na}$ festa literária internacional de Paraty (FLIP) de 2017, seis escritores e escritoras foram convidados/as a realizar intervenções poéticas que contemplassem, de forma bastante híbrida, poesia, fotografia, vídeo, performance, teatro, leitura dramática, entre outras possibilidades. Dentre as leituras apresentadas, queremos destacar a performance "Fruto estranho ${ }^{14 "}$ ", do poeta mineiro Ricardo Aleixo (fig. $01)^{15}$. Mesclando trechos de autoria própria com fragmentos de obras autobiográficas como Diário intimo e Diário do hospício/Cemitério dos vivos, de Lima Barreto ${ }^{16}$, Aleixo problematiza o silenciamento e a exclusão de Barreto, bem como de outros autores e autoras de uma literatura escrita por negros/as. Desse modo, veste um manto de cor preta em que palavras como "têmpora", "adão", "córtex", entre outras, estão escritas com tinta branca, tensionando o discurso científico e biológico historicamente construído, a saber, o racismo científico, que contribuiu para a visão de mundo de negros e negras seriam naturalmente inferiores às populações de cor branca. Com a respiração ofegante, gesticulando excessivamente, ora em silêncio ora falando de modo descompassado, e ensaiando alguns movimentos de dança, Aleixo torna-se a própria plataforma de expressão e meio pelo qual sua mensagem pulsa, um "livro

13 OLIVEIRA, Solange Ribeiro de. Literatura e artes plásticas: o künstlerroman na ficção contemporânea, 1993 , p. 13.

14 "Fruto estranho/Strange Fruit" também é o título de um poema de Abel Meeropol escrito como forma de protesto ao linchamento de dois cidadãos afro-americanos no sul dos Estados Unidos. O poema tornou-se mundialmente conhecido ao ser musicalizado de maneira dolorosa por Billie Holiday. 15 Além de Aleixo, apresentaram-se vários outros poetas e poetisas que são performers, a exemplo de Josely Vianna Baptista, Adelaide Ivánova, André Vallias e Prisca Agustoni 16 Escritor homenageado daquele ano. 
vivo" ou "modelo vivo", para utilizar o título de uma obra do autor em que o mesmo afirma: "Eu jogo palavra no vento e fico vendo ela voar" que a denúncia de Aleixo a respeito do racismo, pobreza e a falência institucional e moral da política e da sociedade brasileira transcende o plano verbal e procura um além - esse que clama pela hibridização, pela mescla de suportes, meios e modos de dizer, revitalizando a própria expressão literária e a experimentação com a linguagem.

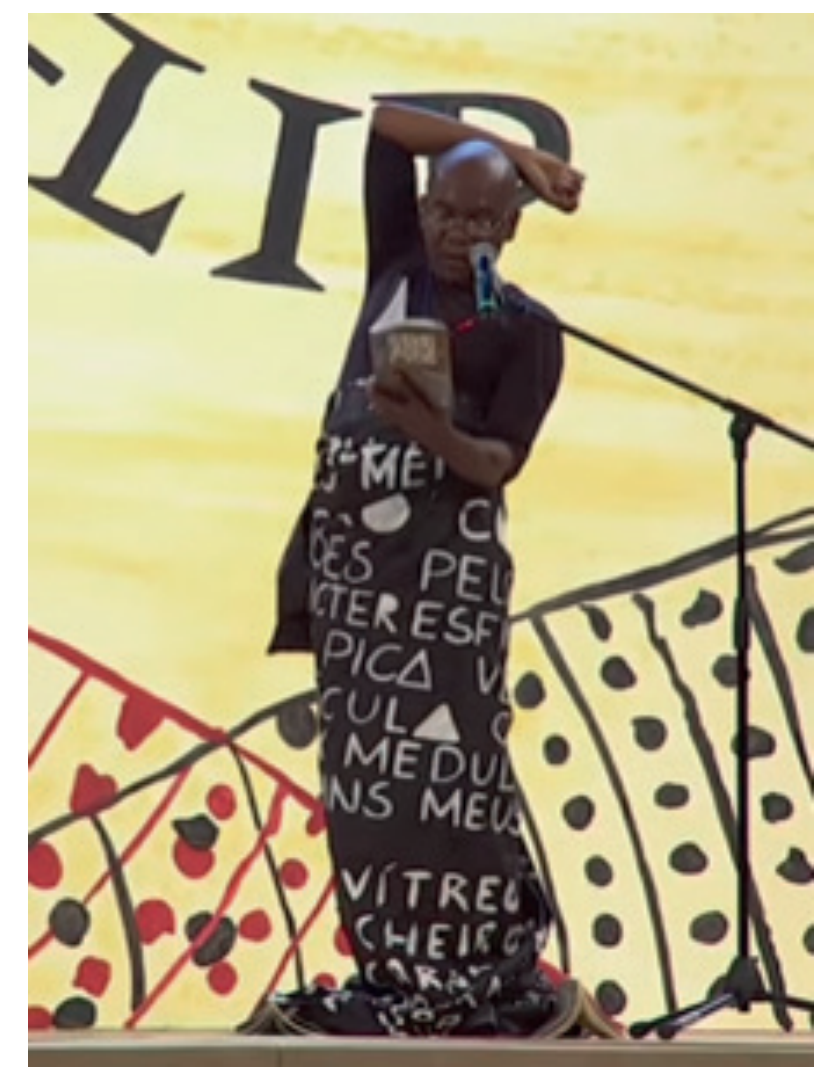

Figura 1 - Performance "Fruto estranho", de Ricardo Aleixo. Fonte: Youtube, 2017.

Ao adentrarmos no campo da crítica, podemos pensar como a opção do escritor, ao realizar uma leitura performática e que por si só já configura uma performance, revela a atualidade do discurso poético entrecruzado por outras vias de manifestação. Como dito anteriormente, o campo de Estudos Interartes/Intermidias é marcado pela amplitude e vastidão, haja vista tudo o que se pode colocar sob o rótulo, por si só maleável e impreciso, de "arte". Neste sentido, o/a teórico/a pode cotejar a literatura

17 ALEIXO, Ricardo. Modelos vivos, 2018, p. 111. 
com o cinema, a pintura, a fotografia, a escultura, a música, a dança, o teatro, entre outras criações. O que nos leva, e talvez o que tenha levado Aleixo, dentre tantas opções possíveis, e igualmente tentadoras, optar por aproximar literatura e performance?

Em seu ciclo de conferências proferidos na década de 80, e que originaram a obra Seis propostas para o próximo milênio ${ }^{18}$, Italo Calvino coloca a visibilidade como uma característica intrínseca ao texto literário. Defende o autor que a habilidade do texto, em menor ou em maior grau, faz com que pudéssemos "ver a cena como se esta se desenrolasse diante de nossos olhos, se não toda a cena, pelo menos fragmentos e detalhes que emergem do indistinto" ${ }^{19}$. O culto à representação visual, da palavra ao imagético, ou vice-versa, como igualmente defende o escritor, nos dá segurança para pensar a relação entre a verbalização literária e a visualização performática. $\mathrm{O}$ leitor pode tanto imaginar/visualizar a cena, quanto perceber seus temas em outras imagens, fazendo com que as conexões entre literatura e performance não se revelem como uma aproximação improvável. Afinal, se o texto é capaz de "jogar com os signos em vez de destruí-los" ${ }^{20}$, fazendo com que a arte seja um constante exercício experimental de rebeldia, de subversão às normas do poder, "em suma, em instituir no próprio seio da linguagem servil uma verdadeira heteronímia das coisas" 21 , a arte de performance partilha do mesmo movimento de insurgência, sendo "basicamente uma arte de intervenção, modificadora, que visa causar uma transformação no receptor" ${ }^{2}$, e, como todo bom ato de insubmissão, "uma linguagem de experimentação"23. Há um sem fim de possibilidades que abarcam o texto performático, desde o corpo do performer, a utilização dos espaços, a confecção de um vestuário que transmita uma mensagem, como é o caso da performance de Aleixo, a utilização ou não de mídias, como a música, o vídeo, as imagens. Em síntese, entre literatura e performance há muito mais o que as aproxima do que as repele, consoante que ambas as formas de expressão sempre foram marcadas pela revolução, transformação e renovação.

Nessa direção é que Graciela Ravetti oferece-nos um excelente ponto de apoio ao pensar na expressão "narrativas performáticas". De acordo com a pesquisadora, assim como a tradição literária já o fizera no passado, há uma série de textos escritos da literatura latino-americana contemporânea que, dada sua configuração, tornam-se

18 Embora o título se refira a "seis propostas", a sexta nunca chegou a ser realizada; o autor pretendia escrevê-la quando chegasse à Universidade de Harvard, mas veio a falecer antes.

19 CALVINO, Italo. Seis propostas para o próximo milênio, 1990, p. 99.

20 BARTHES, Roland. Aula, 2007, p. 27.

21 Ibidem, p. 28.

22 COHEN, Renato. Performance como linguagem, 2013, p. 46.

23 Ibidem, p. 45. 
como um "convite a ir além do estipulado"24, vislumbrando na arte da performance uma possibilidade outra de desdobramento, um próprio "convite à performance". Conforme Ravetti:

[...] utilizo a expressão "narrativa performática" para me referir a tipos específicos de textos escritos nos quais certos traços literários compartilham a natureza da performance, recorrendo à acepção desse termo, em sentido amplo, no âmbito cênico e no político-social ${ }^{25}$.

É especialmente no âmbito político-social que presenciamos o caráter performático de Útero é do tamanho de um punho (2017), da escritora gaúcha Angélica Freitas. Percebemos já em seu título que não se trata de uma mera exposição/ comparação de partes do corpo feminino, mas, dialogicamente, faz com que o leitor leia o signo literário de Freitas compreendendo a intrínseca relação entre o significante, do plano da expressão, com o significado, do plano do conteúdo. Ravetti concentra-se em exemplos da prosa, mas suas propostas podem ser pensadas na direção de uma "volta performática" do poema.

Ademais, não somente o título da obra, mas igualmente o fato de ser escrita por uma mulher, sugere um rumo para a leitura de uma narrativa performática, possibilitando, de antemão, "imaginar formas possíveis de intervenção social, intervenções simbólicas, de restauração, mas também de construção, sobre os retalhos que a memória consegue reerguer e que a vontade projeta" 26 . O plano político, caro aos textos performáticos, já é construído daí. Brincam-se com figuras como "força", "feminilidade, "mulher", "corpo", "útero" e "punho", nas quais a ilusão do real e o título da obra atuam de modo irônico e provocativo para o/a leitor/a.

Contudo, se as proposições de Ravetti revelaram-se frutíferas para discussões iniciais, e, por extensão, para uma visão literário-performática de Um útero é do tamanho de um punho, algumas ponderações precisam ser feitas. Para a intelectual, com o propósito de entender a configuração das narrativas performáticas e seus vínculos, alguns critérios devem estar presentes no texto. Consideremo-nos em diálogo com o trecho de um poema de Angélica:

Considero performativa a narrativa que apresenta um cenário no qual um (ou mais) sujeito(s) aparece(m) em processos de atribuição, com referentes explícitos à realidade material, sendo, por isso, identificáveis, mas nas quais

24 RAVETTI, Graciela. "Narrativas performáticas”, 2002, p. 45.

25 Ibidem, p. 45.

26 Ibidem, p. 59. 


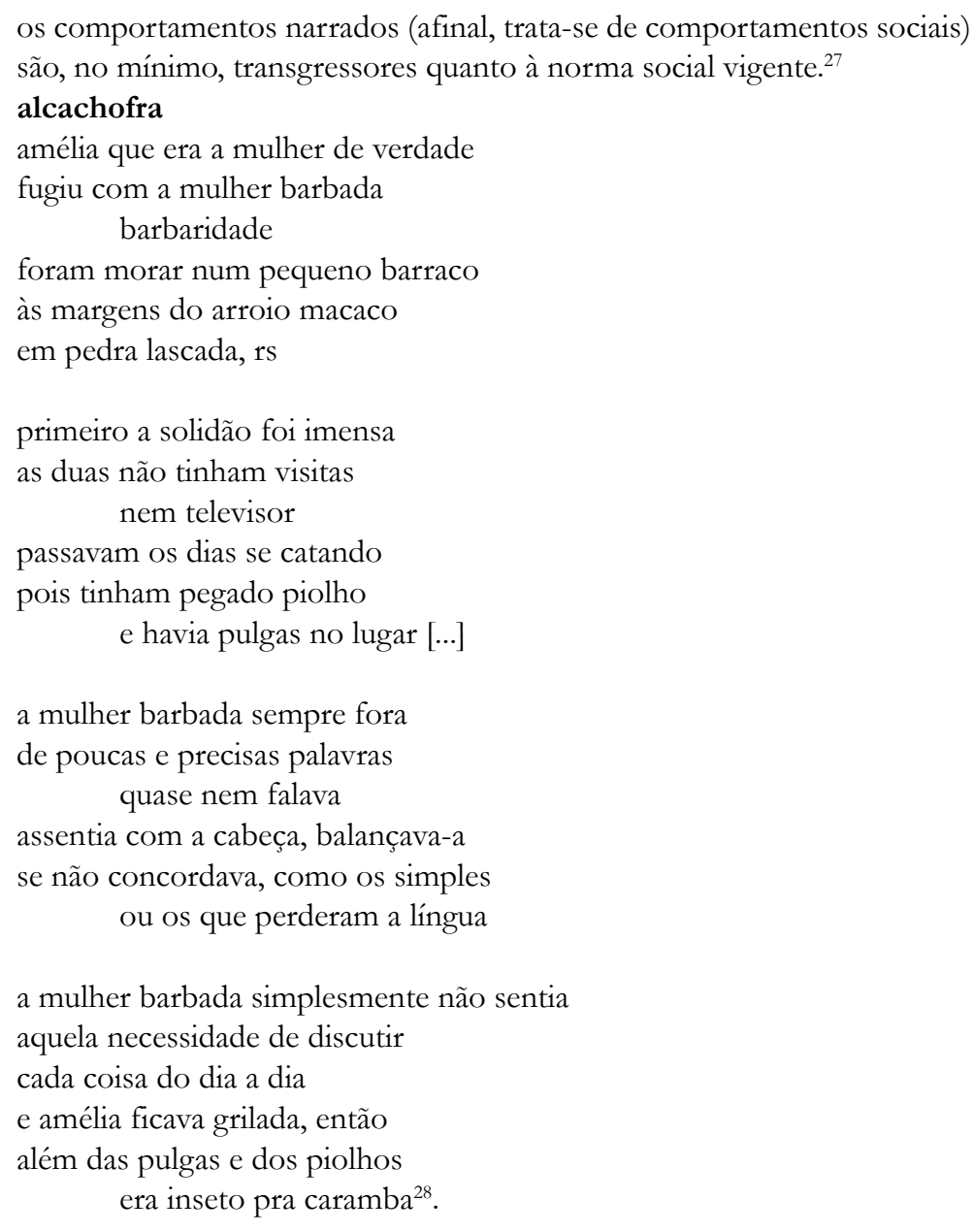

O poema inicia com um intertexto, por via da paródia e sátira da figura de Amélia, conhecida no imaginário brasileiro pela canção "Ai que saudades da Amélia" (1968), composta por Mário Lago e Ataulfo Naves e famosa na voz de Roberto Carlos $^{29}$. Subverte a lógica da música ao inserir Amélia em uma relação homoafetiva “/ fugiu com a mulher barbada/”, “/barbaridade/”, tornando-a uma protagonista lésbica. Todavia, se o relacionamento nasce de uma prática revolucionária, que caminha na

27 Ibidem, p. 49.

28 FREITAS, Angélica. “alcachofra”. In: FREITAS, Angélica. Um útero é do tamanbo de um punho, 2017, p. 24.

29 No contexto brasileiro, a canção é revestida de polêmica. Conforme o artigo "Amélias: imagens da mulher de verdade na canção de Ataulfo Alves", de Amanda Beraldo Faria: "Num ápice de popularidade, o entendimento mais difundido da canção se tornou até verbete de dicionário na língua portuguesa. Para Aurélio, que primeiro inseriu o termo, Amélia é "Do antr. Amélia, do samba "Ai! que saudade da Amélia", de autoria de Ataulfo Alves e Mário Lago.] S. f. Bras. Pop. 1. Mulher que aceita toda sorte de privações e/ ou vexames sem reclamar, por amor a seu homem" (FERREIRA, 2010)". FARIA, Beraldo Amanda. "Amélias: imagens da mulher de verdade na canção de Ataulfo Alves”. Revista brasileira de estudos da canção, 2014, p. 104-124, grifo nosso. 
direção contrária de uma heterossexualidade compulsória, o relacionamento revela-se mais conservador do que progressista, reforçando estereótipos comumente associados ao sexo feminino e masculino. Ora, Amélia representa o termo mulher da maneira como o mesmo foi construído na História: contrapõe-se à mulher barbada, que não sentia "/aquela necessidade de discutir/", "/cada coisa do dia a dia/", reforçando a imagem de que a mulher quer sempre discutir a relação enquanto o "homem" (personificado na mulher barbada) nunca tem tempo para isso. A fina ironia do poema denota uma crítica ao mesmo tempo do padrão heterossexual quanto da frustração homossexual, que acaba por repetir os mesmos comportamentos que parece atacar e reiterar os mesmos discursos violentos e de encaixotamento de papéis de gênero vigentes. Ao final das contas, talvez ainda vivamos, tal qual as personagens, “/em pedra lascada, rs/".

No que diz respeito ao caráter performático do poema, Ravetti elencava a necessidade de "sujeitos em processos de atribuição", cujos "comportamentos narrados" fossem "no mínimo, transgressores quanto a norma social vigente" ${ }^{30}$. Encontram-se no poema, bem como em outros que serão trazidos à baila, as características supracitadas, ora em menor ou em maior grau, ora pela via bivocal do discurso irônico, recurso estilístico comum à poesia de Angélica Freitas. Entretanto, afastamo-nos de alguns pormenores de Ravetti, como o enfoque em situações de um "autobiográfico cênico"31 em que as "imagens e os objetos criados pela ficção se entremesclam com algo do pessoal"32. Não à toa os exemplos literários que Ravetti traga à tona sejam do âmbito das autoficções, o que não é nosso caso. Ainda que na realidade empírica há de se considerar que muitas das violências contidas na obras possam ter sido vivenciadas por Angélica, levando em conta inclusive seu estar no mundo enquanto mulher, lésbica e acima do peso, os poemas não exprimem, pelo menos em nossa leitura, um cunho autobiográfico e de escrita de si - tampouco nossas discussões partem da ordem do bios, sendo muito mais uma consideração em torno da violência contra mulheres de um modo geral.

Dados os devidos distanciamentos com as proposições de Ravetti, mas ainda não perdendo de vista que os poemas de Um útero é do tamanho de um punho, a nosso ver, configuram uma "narrativa performática", consideramos os conceitos expostos em A máquina performática: a literatura no campo experimental, dos argentinos Gonzalo Aguilar e Mario Cámara. Na mesma direção de Ravetti, propõem uma dimensão performática para a literatura, considerando que há textos literários que fazem parte

30 Ibidem, 2002, p. 49.

31 Ibidem, 2002, p. 61.

32 Ibidem, 2002, p. 62. 
de uma "máquina performática", isto é, adquirem novas significações quando seus signos, todos eles, desde "um gesto, um tom de voz, um corpo que se exibe, até um perfume" 33 , sejam trabalhados de modo que o texto abra-se para uma multiplicidade de conexões, que talvez não pudessem ser feitas caso o ato de leitura fosse fechado somente na palavra escrita, sem que se criassem ligações com outros campos de sentido e discursos poéticos. Como apontam os autores, "a ideia é convocar a performance para mostrar que sua presença transforma as leituras possíveis de uma obra”34, logo, aproximando-se da ideia de céu estrelado de Barthes (1992) quando destacam que "O que está em crise é hegemonia textual como única fonte de autoridade"35.

Desse modo, podemos pensar no exercício de diálogo entre literatura e performance com o poema que abre Um útero é do tamanho de um punho, o provocativo "porque uma mulher boa":

\author{
porque uma mulher boa \\ é uma mulher limpa \\ e se ela é uma mulher limpa \\ ela é uma mulher boa \\ há milhões, milhões de anos \\ pôs-se sobre duas patas \\ a mulher era braba e suja \\ braba e suja e ladrava \\ porque uma mulher braba \\ não é uma mulher boa \\ e uma mulher boa \\ é uma mulher limpa \\ há milhões, milhões de anos \\ pôs-se sobre duas patas \\ não ladra mais, é mansa \\ é mansa e boa e limpa ${ }^{36}$.
}

33 AGUILAR, Gonzalo; CÁMARA, Mario. A máquina performática, 2017, p. 10.

34 Ibidem, 2017, p. 13.

35 Ibidem, 2017, p. 12.

36 FREITAS, Angélica. “porque uma mulher boa”. In: FREITAS, Angélica. Um útero é do tamanho de um punho, 2017, p. 11. 
É perceptível que em questão de forma o poema não corresponda a uma versificação e metrificação tal qual se seguiam os modelos grecos-latinos, ou seja, distancia-se da concepção clássica de poema. No entanto, há em seu interior elementos mais do que necessários para que seja estudado enquanto um poema de grande força, sobretudo pela questão de ritmo ali presente.

De início, pensamos que merece destaque a questão do ritmo que, dado os versos enxutos, faz com que o leitor crie uma associação direta de "mulher boa = mulher limpa" ou vice-versa. Por limpeza, podemos pensar não só a ausência de sujeira, mas também a ausência de qualquer traço de rebeldia, de não-sujeição às regras impostas pela sociedade, de um sujo que não atinge somente o corpo feminino no que ele tem de constituição, mas o que ele deve e não deve fazer no nível de comportamento, moral e ética; uma limpeza que atinge a estrutura e funcionamento desse ente.

Outrossim, as imagens suscitadas pelo poema fazem com que a associação reversa seja a de mulher braba = algo ruim, explicitado pelos versos "porque uma mulher braba/não é uma mulher boa". O adjetivo braba, tal qual o anterior limpa, parece incitar uma leitura maior. A mulher ser braba/brava, não se trata meramente de um estado associado ao nervosismo, mas de tentar esquivar-se das regras do jogo, de lutar contra o sistema imposto, patriarcal, machista e falocêntrico, de ser aquela mulher que desafia, acima de tudo, o sujeito e os ditames da dominação masculina.

Contudo, o poema encerra com um tom do que ainda se percebe na contemporaneidade em relação à mulher, já que a mesma, por diversas vezes e forçosamente, "não ladra mais, é mansa/é mansa e boa e limpa". Isto é, caso a mulher veja-se tentada a quebrar as imposições feitas pelos sistemas de dominação vigentes, muito provavelmente será repreendida e com isso voltará ao ritmo zero de sua sujeição, retornando a ser uma figura assujeitada, conformada, que não pode e não deve lutar pelos seus direitos.

Já com esse primeiro poema, é possível perceber como o corpo feminino é um local a ser vigiado, ou, nos termos de Foucault (2000), um dispositivo. Para o pensador, o dispositivo é:

[...] um conjunto decididamente heterogêneo que engloba discursos, instituições, organizações arquitetônicas, decisões regulamentares, leis, medidas administrativas, enunciados científicos, proposições filosóficas, morais, filantrópicas. Em suma, o dito e o não dito são os elementos do dispositivo. O dispositivo é a rede que se pode tecer entre estes elemen$\operatorname{tos}^{37}$. 
Nesse sentido, considerando a característica heterogênea do dispositivo, é possível pensar que seu agenciamento de controle é coerente com a imposição que prega? Não é o que nos mostra a artista visual paraense Berna Reale com a performance "Sim senhor" (fig. 02), datada de 2010:

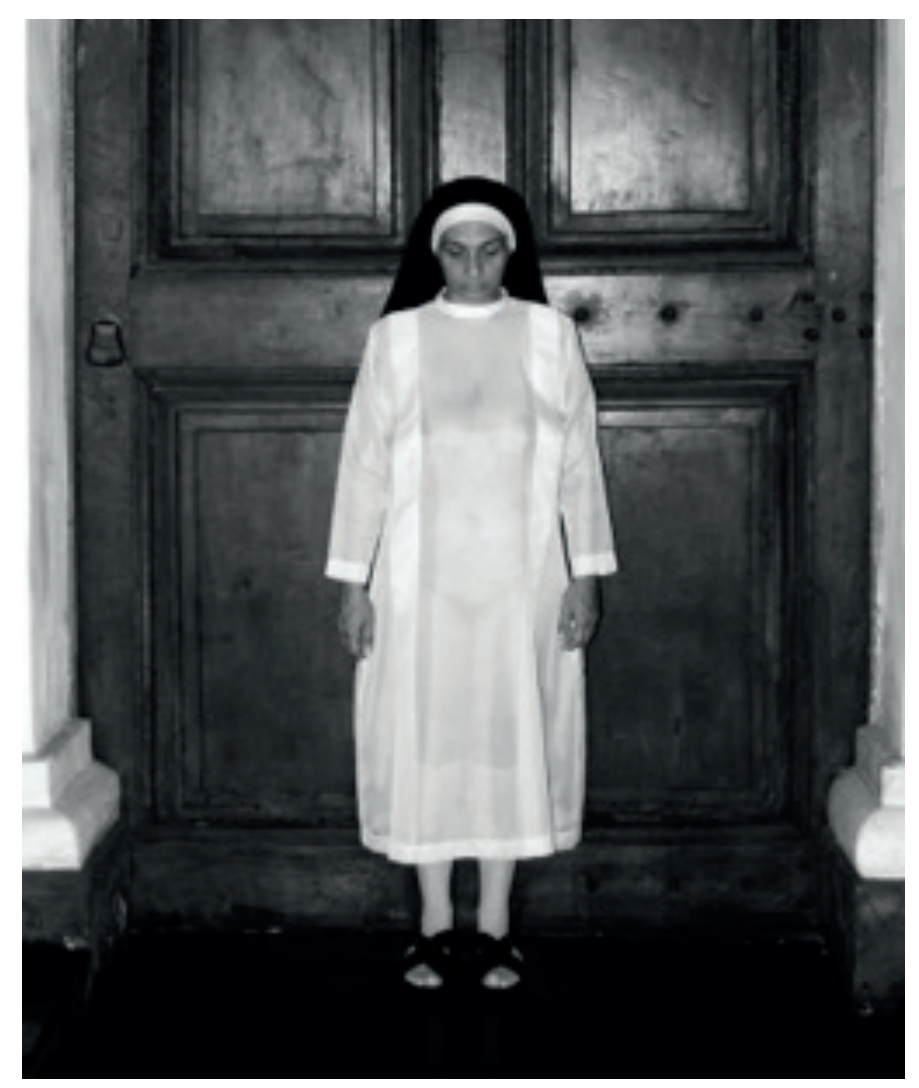

Figura 2 - Performance “Sim senhor”, de Berna Reale. Fonte: Galeria Nara Roesler, 2010.

Vestida com um hábito de freira, Berna retoma as mulheres "limpas" do poema de Angélica Freitas, haja vista a concepção do discurso religioso sobre a entrega que uma freira deve fazer em relação ao seu corpo e suas vontades, renunciando piamente à sua sexualidade ou aquilo que se chamaria de "desejos carnais". No entanto, a performance estabelece um jogo de contrários e paradoxos ao abordar uma certa putrefação moral da Igreja Católica, questionando o poder de padres que historicamente desviaram de suas atribuições e violentaram freiras, como já admitido pelo Vaticano, com casos, inclusive, no Brasil. Estabelece-se, então, um jogo de contrastes, já que Berna veste um hábito religioso transparente, revelando o corpo nu que deveria estar coberto, e podendo ser vista como objeto sexual mesmo portando trajes que supostamente a afastariam do desejo sexual de outrem. A cabeça resignada da artista, que olha para baixo, de semblante triste e inconformado, associada ao título da performance, "Sim senhor", parece ironizar não só o juramento que as irmãs religiosas devem fazer à 
vida religiosa e ao Deus cristão, mas também ao triste consentimento dos abusos e violências sexuais cometidos contra seus corpos, talvez parte de um plano maior ainda não explicado em termos racionais.

Tal performance nos lembra de casos como o de 28 freiras que engravidaram de padres ou de uma freira que morreu durante um aborto clandestino e teve sua missa fúnebre celebrada pelo mesmo padre que a agrediu sexualmente ${ }^{38}$. Faz-nos lembrar da insustentável leveza da crueldade de uma determinada visão de mundo - dentro e fora do discurso religioso - e que na verdade se instaura em todas as instâncias da sociedade, colocando as mulheres constantemente em perigo, sejam elas mulheres brabas ou boas, religiosas ou não. É o sujeito colocado no estado de coisa, coisificado, e, no caso das mulheres, aprisionado pela lógica do sexo/gênero. Em "mulher de vermelho", poema de Angélica Freitas, que, inclusive, fez parte do banco de questões do Exame Nacional do Ensino Médio (ENEM) de 2018, a autora reflete sob a ótica do corpo feminino julgado pelo modo que se veste:

o que será que ela quer
essa mulher de vermelho
alguma coisa ela quer
pra ter posto esse vestido
não pode ser apenas
uma escolha casual
podia ser um amarelo
verde ou talvez azul
mas ela escolheu vermelho
ela sabe o que ela quer
e ela escolheu vestido
e ela é uma mulher
então com base nesses fatos
eu já posso afirmar
que conheço o seu desejo
caro watson, elementar:
o que ela quer sou euzinho
sou euzinho o que ela quer
só pode ser euzinho
o que mais podia ser ${ }^{39}$

38 Cf. "Vaticano admite abuso de freiras por padres". Disponível em: https://www1.folha.uol.com.br/ fsp/mundo/ft2103200101.htm. Acesso em: 01 maio 2020.

39 Ibidem, 2017, p. 31. 
Comenta a autora que "Quem está falando no poema é um homem que vê uma mulher com um vestido vermelho. Ele pensa que ela se vestiu assim porque quer chamar a atenção dele [...] ele estabeleceu preceitos da psicologia feminina" "40, ideia comprovada pelos versos finais "sou euzinho o que ela quer/só pode ser euzinho". A ideia de que o vestido vermelho, no caso do poema, é o símbolo de uma provocação, repercute nas mais diversas esferas acerca do comportamento feminino. Estabelecemse determinados padrões absurdos de comportamento (formadores das mulheres limpas), que determinam que seu não cumprimento ocasione uma resposta esperada, como no caso do sujeito masculino do poema que acredita que esteja sendo provocado. Em se tratando da provocação desse outro que é masculino, podemos partir do poema para a performance "Duas" (fig. 03), de Berna Reale, que nasce de um recente caso ocorrido no Oriente Médio.

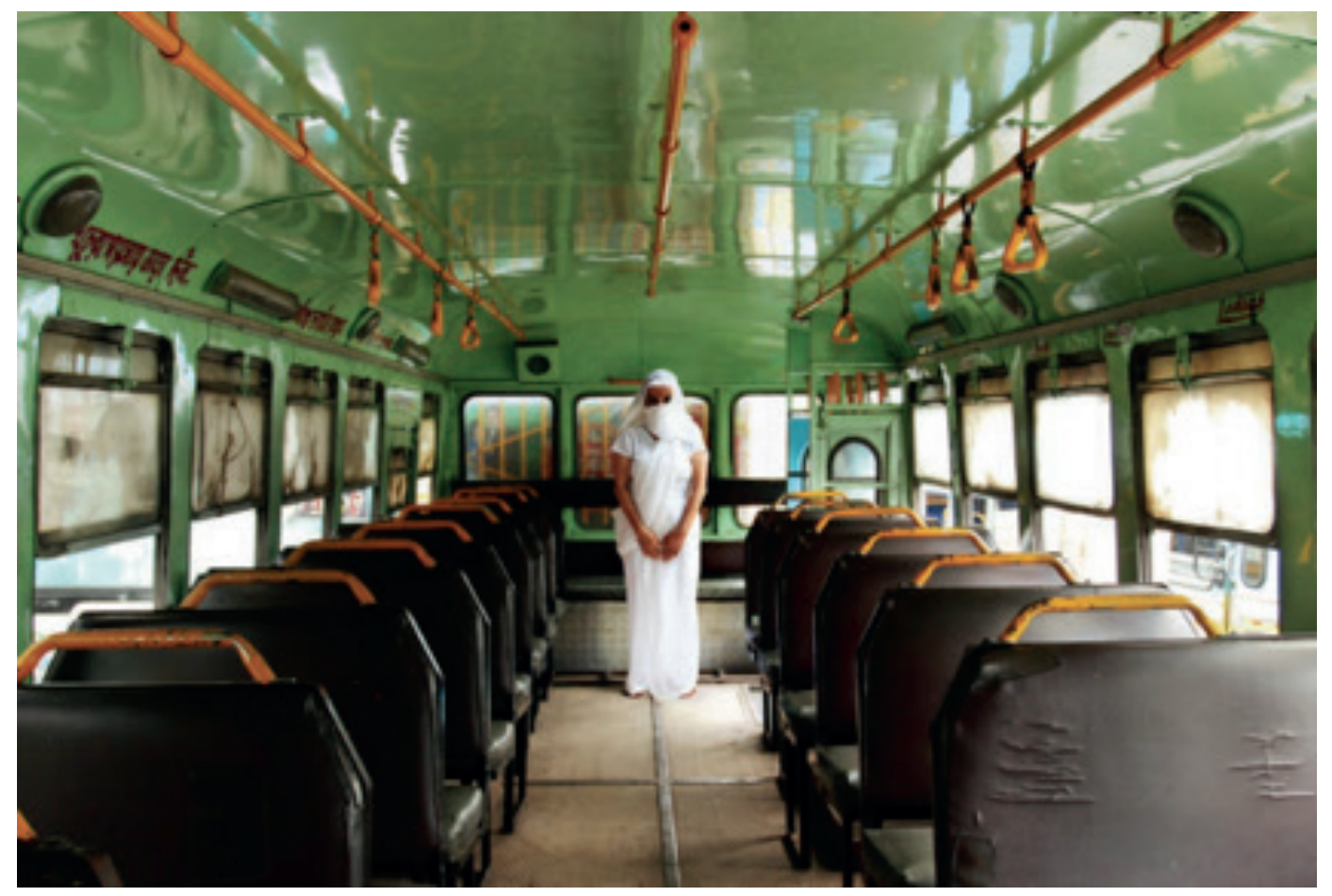

Figura 3 - Performance "Duas”, de Berna Reale. Fonte: Galeria Nara Roesler, 2015.

Em 16 de Dezembro de 2012, na Índia, uma estudante de fisioterapia foi estuprada coletivamente dentro de um ônibus ao retornar do cinema com um amigo. O caso chocante e que foi melhor apresentado ao mundo pelo documentário Filha da Índia (2015), de Leslee Udwin, choca pela naturalização do discurso dos algozes

40 Cf. https://g1.globo.com/educacao/enem/2018/noticia/2018/11/08/autora-de-poema-que-caiu-no-enem-resolve-questao-da-prova-indicando-como-fugir-de-erro-na-interpretacao.ghtml. Acesso em: 01 maio 2020. 
que não sentiam nenhum remorso pela brutalidade de seu ato. Nas palavras de seu advogado: "No momento em que ela saiu de casa com um rapaz que não era nem seu marido e nem seu irmão, deixou para trás sua moral e sua reputação e tornou-se apenas uma mulher" ${ }^{41}$. Novamente, como na performance anterior, Berna representa um ser fragilizado e aparentemente perdido, centralizado no espaço do ônibus, como alvo a ser visto por tudo e por todos. Trajada com um Sari branco, que encarna o ideal indiano de boa moça, protegendo o corpo feminino que não deve ser visto, Berna questiona uma sociedade que, ao desviar-se dos próprios ideais que pretende defender, continua criando situações para legitimar suas injustas atitudes. Talvez, por isso que o título da performance seja "Duas", já que, como dito pelo advogado daqueles que violentaram a estudante, havia uma mulher antes que a jovem resolvesse andar de ônibus à noite com um amigo e outra mulher, criada a partir de tal ato. $\mathrm{Na}$ verdade, talvez essas duas tenham sido desde sempre uma só, aquela que será atacada, aquela que não merece viver. Tal qual a "mulher de vermelho", que aparentemente denota por sua escolha de roupa - "não pode ser apenas/uma escolha casual" - uma determinada intencionalidade, assim deve ser julgada a estudante. O "o que ela quer sou euzinho" segue alinhado para um contexto ainda mais punitivo de "o que ela queria e/ou merecia era isso". Tanto no poema quanto na performance, percebe-se a programação de um alerta para o corpo feminino, como se determinadas cores, roupas e comportamentos devessem ser evitados, pois, caso contrário, algo terrível poderá acontecer e, ainda pior, que a mulher pareceria querê-lo Esse posicionamento de papéis, tão caro à sociedade contemporânea, é somente mais um dos obscurantismos da história, de conferir ao ente mais fraco a total submissão àquele que o ataca, ou inverter determinadas posições no mundo.

A presença do corpo em literatura e performance, nos poemas de Angélica Freitas e nas performances de Berna Reale, bem como o diálogo entre duas manifestações distintas, denota não só uma visão estética permeada por determinadas visões éticas, mas também a necessidade de "passar uma mensagem, talvez até algumas advertências, sobre a realidade social anacrônica das mulheres em pleno século XXI" Vislumbra-se o espaço político-social das "narrativas performáticas", como assinala Ravetti (2002) e da composição de uma "máquina performática" em que "nenhum signo é mais importante do que o outro" ${ }^{43}$.

41 Cf. https://epoca.globo.com/colunas-e-blogs/ivan-martins/noticia/2015/09/estupradores-nao-sentem-remorso.html. Acesso em: 01 maio 2020.

42 KUHNERT, Duda. "Nas artes", 2018, p. 76.

43 AGUILAR, Gonzalo; CÁMARA, Mario. A máquina performática, 2017, p. 11. 
Compreendendo que a literatura é compósita em seu interior e a performance explosiva em seu exterior, é preciso que consideremos a estética contemporânea como um entrecruzamento de meios e suportes, derrubando os muros que possam enquadrar a linguagem artística enquanto noção una de propriedade. A possibilidade de diálogo entre Angélica Freitas e Berna Reale em nada contribui para a diminuição da leitura do texto ou da performance. Ao contrário, aumentam-se as possibilidades de interpretações e relações de sentido, evocando a própria palavra para além de sua significação verbal, orientação que nos ensina Octavio Paz.

[...] um poema que não lutasse contra a natureza das palavras, obrigando-as a ir mais além de si mesmas e de seus significados relativos, um poema que não tentasse fazê-las dizer o indizível, permaneceria uma simples manipulação verbal. O que caracteriza o poema é sua necessária dependência da palavra tanto como sua luta por transcendê-la. Esta circunstância permite uma indagação sobre a sua natureza como algo único e irredutível e, simultaneamente, considerá-lo como uma expressão social inseparável de outras manifestações históricas ${ }^{44}$.

Nesse sentido, antes de considerar as imagens de Amélia, do corpo da mulher limpa ou suja, braba ou boa ou que se veste de vermelho, somente enquanto signos verbais e representações contidas no texto de Angélica Freitas, por que não imaginar tais figuras no âmbito de outras manifestações artísticas, quer seja o da performance, quer seja o de outra forma de linguagem, inserindo-os no contexto de uma narrativa/ máquina performática? Por seu espaço híbrido por excelência, a performance revelouse como terreno fértil de experimentação e diálogo. Quem sabe assim a conversa entre as artes possa vingar o mundo do texto e da representação poética enquanto simulacro do mundo.

\section{Referências Bibliográficas}

AGUILAR, Gonzalo; CÁMARA, Mario. A máquina performática: a literatura no campo experimental. Trad. Gênese Andrade. Rio de Janeiro: Rocco, 2017.

ALEIXO, Ricardo. Modelos Vivos. Belo Horizonte: Crisália, 2010.

ALEIXO, Ricardo. "Fruto estranho", 2017. Disponível em: https://www.youtube. com/watch?v=We5PnoIFhv4. Acesso em: 01 maio 2020.

44 PAZ, Octavio. Signos em rotação, 2015, p. 52. 
BARTHES, Roland. S/Z. Trad. Léa Novaes. Rio de Janeiro: Nova Fronteira, 1992.

BARTHES, Roland. Aula. 15. ed. Trad. Leyla Perrone-Moisés. São Paulo: Cultrix, 2007.

CALVINO, Italo. Seis propostas para o próximo milênio. 3. ed. Trad. Ivo Barroso. São Paulo: Companhia das letras, 1999.

COHEN, Renato. Performance como linguagem. São Paulo: Perspectiva, 2013.

FARIA, Amanda Beraldo. "Amélias: imagens da mulher de verdade na canção de Ataulfo Alves". Revista brasileira de estudos da canção. n. 6, p. 104-124, jul./dez. 2014. Disponível em: http://rbec.ect.ufrn.br/data/_uploaded/artigo/N6/RBEC_N6_ A8.pdf. Acesso em: 01 maio 2020.

FOUCAULT, Michel. Microfísica do poder. 15. ed. Trad. Roberto Machado. Rio de Janeiro: Graal, 2000.

FREITAS, Angélica. Um útero é do tamanho de um punho. São Paulo: Companhia das letras, 2017.

KUHNERT, Duda. "Nas artes". In: HOLLANDA, Heloisa Buarque de. (Org.). Explosão feminista: arte, cultura, política e universidade. 2. ed. São Paulo: Companhia das Letras, 2018, pp. 75-104.

OLIVEIRA, Solange Ribeiro de.. Literatura e artes plásticas: o künstlerroman na ficção contemporânea. Ouro Preto: UFOP, 1993.

PAZ, Octavio. Signos em rotação. 4. ed. Trad. Sebastião Uchoa Leite. São Paulo: Perspectiva, 2015.

RAVETTI, Graciela. "Narrativas performáticas”. In: RAVETTI, Graciela; ARBEX, Márcia (Orgs.). Performance, exílio, fronteiras: errâncias territoriais e textuais. Belo Horizonte: Departamento de Letras Românicas, Poslit/FALE/UFMG, 2002, pp. 47-68.

REALE, Berna. “Sim senhor”, 2010. Disponível em: https://nararoesler.art/usr/ library/documents/main/69/gnr-berna-reale-portfolio.pdf. Acesso em: 01 maio 2020. 
REALE, Berna. "Duas”, 2015. Disponível em: https://nararoesler.art/usr/library/ documents/main/69/gnr-berna-reale-portfolio.pdf. Acesso em: 01 maio 2020.

Submissão: 08/05/2020

Aceite: $30 / 07 / 2020$

https://doi.org/10.5007/2176-8552.2020.e73656

Esta obra foi licenciada com uma Licença Creative Commons Atribuição-NãoComercial 4.0

Internacional. 